\title{
Influence of Leadership Style on Organizational Performance of Primary Teachers Training Colleges in Lake Victoria Region of Kenya
}

\author{
K'opiyo Patrick Lumumba1, Enose M. W. Simatwa르, Kembo Jane ${ }^{3}$ \\ ${ }^{1}$ Department of Foundations, Management and Policy, Rongo University, Migori, Kenya \\ ${ }^{2}$ Department of Education Policy and Management, Tom Mboya University College, Homabay, Kenya \\ ${ }^{3}$ Department of Curriculum Instruction and Media, Rongo University, Migori, Kenya \\ Email: lumumbakopiyo@yahoo.com
}

How to cite this paper: Lumumba, K. P., Simatwa, E. M. W., \& Jane, K. (2021). Influence of Leadership Style on Organizational Performance of Primary Teachers Training Colleges in Lake Victoria Region of Kenya. Creative Education, 12, 2228-2251. https://doi.org/10.4236/ce.2021.129170

Received: July 21, 2021

Accepted: September 26, 2021

Published: September 29, 2021

Copyright (c) 2021 by author(s) and Scientific Research Publishing Inc. This work is licensed under the Creative Commons Attribution-NonCommercial International License (CC BY-NC 4.0). http://creativecommons.org/licenses/by-nc/4.0/

c) (7) \&) Open Access

\begin{abstract}
The purpose of this study was to investigate empirically the influence of principals' leadership styles on the organizational performance of primary teachers training colleges in Lake Victoria Region of Kenya. Independent variables comprised Laissez faire and autocratic leadership styles, while the dependent variable was organizational performance. The study employed a quantitative method approach with questionnaires as the instruments for data collection. The target population for this study was 245 tutors and 9 principals in the 5 public and 4 private primary teachers training colleges. The study sample was 225 tutors and the 9 principals. Leadership styles were measured using the adapted version of the Multi-factor Leadership Style Questionnaire. The study found that both Laissez faire and autocratic leadership styles were less exhibited by principals of PTTCs in Lake Victoria Region of Kenya. Laissez faire leadership style was least exhibited. The study also revealed that both Laissez faire and autocratic leadership styles negatively influenced the organizational performance of PTTCs. Lastly demographic characteristics did not have statistically significant influence on organizational performance of PTTCs in the Lake Victoria Region of Kenya.
\end{abstract}

\section{Keywords}

Leadership, Leadership Style, Laissez faire Leadership, Autocratic Leadership, Organizational Performance

\section{Introduction}

The role of a leader has always been highlighted as being a key driver of em- 
ployee engagement. A leader who has genuine commitment to the employees' well-being and interacts with the employees has influence on employee engagement. According to $\mathrm{Xu}$ and Cooper (Xu \& Cooper, 2011), the engagement among the employees increase when they feel involved through a collaborative leadership style. Trust in the leader, his support and a friendly environment lead to employee engagement. Leading effectively requires competence, skill and suitable leadership styles. Leadership is viewed as the process of influencing, motivating and enabling others to understand and agree to contribute collectively to the effectiveness and success of the organization's shared objectives of which they are members (Yukl, 2013). Leadership Style therefore, is the manner and approach of providing direction, implementing plans, and motivating people; the combination of traits, characteristics, skills and behaviors that leaders use when interacting with their subordinates (Jeremy et al., 2012). Without positive daily interactions with members of staff, or the human side of the work, the other aspects of a leader's responsibilities will suffer (Cangemi, 2008).

In a PTTC, the principal is the leader who coordinates, keeps balance and ensures the harmonious development of the whole institution by molding traditions for organizational goal achievement. Tutors are key players in PTTCs, and it is through their involvement and commitment that PTTCs become successful. The relationship between a principal and tutors is interdependent in nature (Kerego \& Mthupha, 1997), and both parties affect one another's ability to achieve positive results. PTTCs' principals should therefore provide and articulate leadership style which gears the colleges towards the integration of both the organization and personal goals.

A number of studies have explored the relationship between leadership and organizational performance (Chung \& Lo, 2007; Rowold, 2011). However, there is still a lack of empirical studies to explain the nature and confirm the existence of a relationship between leadership style and organizational performance in the African context and across various organizations (Cloete, 2011). This study is set to investigate the extent to which principals' leadership styles influence specifically organizational performance of PTTCs in Lake Victoria Region of Kenya.

\subsection{Purpose of the Study}

This study investigated the leadership styles of principals in Primary Teachers Training Colleges in the Lake Victoria Region of Kenya. It specifically sought to determine the influence of Laissez faire and autocratic leadership styles on organizational performance of PTTCs in Lake Victoria Region of Kenya.

\subsection{Objectives of the Study}

The objectives of study are to: 1) investigate whether Laissez faire leadership is exhibited by principals of PTTCs in Victoria Region of Kenya; 2) investigate whether autocratic leadership is exhibited by principals of PTTCs in Victoria Region of Kenya; 3) establish influence of principals' laissez-faire leadership on 
organizational performance of Primary Teachers Training Colleges in Lake Victoria Region of Kenya; 4) examine influence of principals' autocratic leadership on organizational performance of Primary Teachers Training Colleges in Lake Victoria Region of Kenya.

\subsection{Research Question}

The following four research questions were formulated to guide the research study:

1) Do principals of primary teachers training colleges in Lake Victoria Region of Kenya practice Laissez faire leadership styles?

2) Do principals of primary teachers training colleges in Lake Victoria Region of Kenya practice autocratic leadership styles?

3) What is the influence of Laissez faire leadership on the organizational climate of PTTCs?

4) What is the influence of autocratic leadership on the organizational climate of PTTCs?

\subsection{Scope of the Study}

This study was confined only to counties in Lake Victoria Region of Kenya, namely: Migori, Homabay, Kisii, Kisumu and Siaya. The study involved principals and tutors of the nine selected PTTCs only. This study focused only on laissez-faire leadership, autocratic leadership and organizational performance.

\subsection{Significance of the Study}

The findings of this study is meant to contribute to the existing body of knowledge on the appropriate leadership styles available for principals of PTTCs. Successful principals need multiple lenses and skills in strategizing-looking at old problems in a new light, as well as confronting new challenges with different tools and reactions. Findings of the study are to enrich the literature leadership styles employed by leaders for educational planners and administrators in Kenya.

\subsection{Conceptual Framework}

The conceptual framework in Figure 1 was developed after review of existing literature to investigate the research questions at hand. The diagram underpins the interrelationships between three variables. PTTCs principals' leadership styles: Laissez faire and autocratic formed the independent variables. Organizational performance has covered PTTCs performances in Primary Teachers Education examinations. Tutors' demographic characteristics, namely gender, age, educational level, teaching experience, tenure in current PTTC form intervening variable.

\section{Literature Review}

\subsection{Theories of Leadership}

One of the many indicators of a successful organization is its effective leadership. 


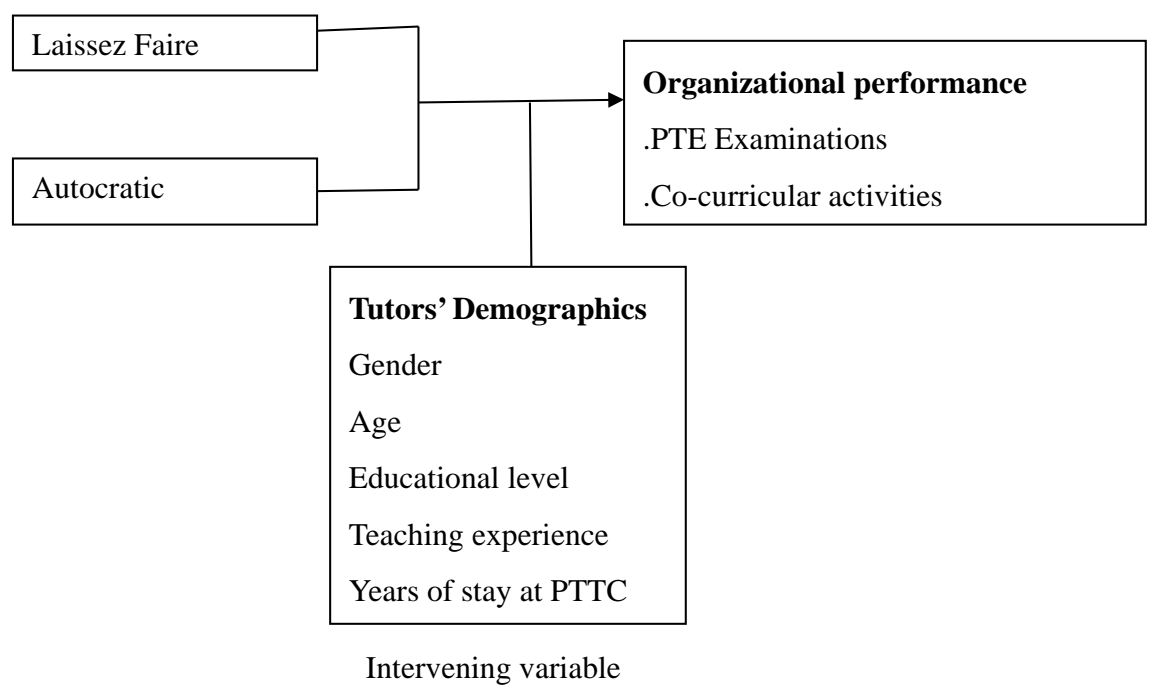

Figure 1. Conceptual frameworks showing the influence of leadership styles on Organizational performance of PTTCs. Source: Researcher constructed (2019).

Leading effectively requires competence, skill and suitable leadership styles. Leadership is viewed as the process of influencing, motivating and enabling others to understand and agree to contribute collectively to the effectiveness and success of the organization's shared objectives of which they are members (Yukl, 2013). According to Armstrong (2012), a leadership style is the approach used by leaders to exercise their leadership function. It is said to be a particular behavior applied by a leader to motivate his or her subordinates to achieve the objectives of the organization (Ng'ethe et al. 2012). The styles of leadership included in this study are laissez-faire and autocratic.

\subsection{Laissez faire Leadership Theory}

Laissez-faire is a French phrase that means let it be and describes leaders who allow followers to work without supervision (Nwokocha \& Iheriohanma, 2015). It is the kind of leadership where the leader is inactive, rather than reactive or proactive. The laissez-faire leadership style, also known as the "hands-off" style or free reign, is one in which the leader (principal) provides little or no direction and gives tutors as much freedom as possible. According to Gill (2014) it means leaving subordinates to complete tasks and jobs in the way they choose without adherence to any strict policies or procedures. Principals who adopt the laissez-faire leadership style exercise little control over the tutors and let the tutors have freedom to carry out their assigned tasks without direct supervision ( Wu \& Shiu, 2009).

True laissez-faire is in fact "non-leadership" because the leader has almost no influence over the group (Bass, 1999). Bass (1985) describes the Laissez faire leadership style as one in which the leader has no belief in his/her own ability to supervise. He further states that the leader has no clear set goals towards how 
they may work, do not help the group in making decisions and so leaves too much responsibility with their subordinates. According to Puni et al., (2014), the laissez-faire leader avoids controlling his employees and so only relies on the few available employees who are loyal to get a task done. A Laissez faire leader does not believe in employee development as they believe that employees can take care of themselves (Puni et al., 2014).

The behavior of a laissez-faire leader makes it difficult to distinguish the leader from the followers. Principals who use this style of leadership believe that there should be no rules and regulations since everybody has inborn sense of responsibility. The philosophical assumption underlying laissez-faire leadership is that naturally human beings are unpredictable and uncontrollable and trying to understand people is a waste of time and energy. Under this style, the principal tries to maintain a low profile, respects all departments and sections within the institution, trying not to create waves of disturbance, and relies on the few available loyalists to get job done (Northouse, 2007).

The laissez-faire principal lives and works with whatever structure is put in place without any suggestions or criticisms. Goals and objectives are established only when necessary and required. Such a principal shuns decision-making as much as possible, and would avoid communication but communicates only when needed. Thus, the business of staff development is not a concern of the Laissez faire leader principal, who believes that tutors can take care of themselves (Rowe, 2007). The laissez-faire leadership style is passive, unassertive and tends to allow self-empowerment among tutors (Harper, 2012). Due to frequent absence and lack of involvement when making important decisions, the laissez-faire principal drives tutors to self-management.

\subsection{Autocratic Leadership Theory}

Autocratic leadership style, also called coercive or dictatorship, involves the leader retaining as much power and decision-making authority as possible (Farrell, 2009). In other words, autocratic leadership involves absolute, authoritarian control over a group; such a principal is characterized as domineering. In autocratic leadership style, the principal determines policy and assigns tasks to tutors without consulting them. Wu and Shiu (2009) explained that, autocratic or authoritarian leadership is gained through punishment, threats, demands, orders, rules, and regulations. The tutors working under autocratic principals carry out the principal's directives without asking questions and there are no group inspired decisions. The principal centralizes authority in decisions making and supervises work in close detailed manner than in general form.

The autocratic leader applies McGregor's (1966) Theory X which assumes that the average person dislikes work and will avoid it unless directly supervised, the employees must be coerced, controlled and directed to ensure that the organizational objectives are met; the threat of punishment must exist within an organization, and employees prefer to be led this way to avoid responsibility. Autocratic leadership also assumes that people are relatively un-ambitious and their 
prime driving force is the desire for security (Mat, 2008).

Leadership include unilateral rule-making, task-assignment, and problem solving while the roles of authoritarian followers include adhering to the leader's instructions without asking question or commenting. Autocratic leaders inform their subordinates on what must be done, how it should be done and when it must be completed. This kind of principal often ignores suggestions made by staff members. When the leader is overbearing, he/she can undermine the egalitarian spirit of an effective team and compromises positive organizational climate. The leader does not have confidence in his subordinates. The leader rarely praises, rather he criticizes a lot, leading to followers' loss of confidence in him and become less committed to their work. Findings by Boyatzis, Goleman, and Mckee (2002) indicate that the autocratic leadership is the least effective in most situations, because followers become emotionally cold from intimidation and therefore, the work environment is affected negatively.

\subsection{Organizational Performance Theory}

According to Farlex (2012), it is the actual output/results of an organization obtained when measured against its intended outputs (goals and objectives). Existing labor literature has shown that employees tend to put in their best, work effectively and efficiently if the work environment is conducive and the leadership and corporate executives demonstrate the flexibility that they often demand of their employees (Fernández, 2003). Organizational performance assesses how an organization is able to meet its stated objectives over time. Organizational performance relates to how efficient, effective, relevant and viable an organization is. McNamara et al. (2011) states that organizational performance involves recurring activities that establish organizational goals, monitors progress towards goals and makes adjustments to achieve the goals more effectively and efficiently.

Effectiveness is the measure of the degree to which the institution's service offered meet the customer's expectations. Efficiency is the utilization of the resources within appropriate cost structures; relevance is the ability to adapt to changing environments to satisfy the stakeholders' current needs, while viability is the ability to maintain sustainable operational base for meeting obligations as they fall.

\subsection{Demographic Characteristics}

Greenberg (2004) defines workplace demographic characteristics as the variety of differences between people in an organization including race, ethnic group, gender, age, education background, tenure, personality, cognitive style, and organizational function. Bell (cited in Thakur, 2015) also defines demographic characteristics as personal statistics on information such as gender, age, education level, income level, marital status, occupation, religion, birth rate, death rate, average size of family, average age at marriage. Fletchl (2010) points out 
that the demographic characteristics have an influence on whether employees will be committed to their work or not. He observes that how well the employee performs, how many years they are ready to dedicate in service and how well they act in the best interest of the firm's objectives heavily depends on how much the organizations take care of the needs that are related to their demographic characteristics. According to Hayles and Mendez (1997) diversity allows increased creativity, a wider range of perspectives, better problem definition, more alternatives and better solutions as noted in Thakur (2015). This study has been delimited to five demographic areas: gender, age, educational level, teaching experience, and tenure in current PTTC.

\subsection{Influence of Leadership Styles on the Organizational Performance of PTTCs}

Khumalo (2015) in a study of a related topic in South Africa cited several studies on influence of leadership on organizational climate. The studies confirmed that organizational commitment tends to heighten for those employees whose management or leadership give them the opportunity to partake in decision-making (Steyrer, Schiffinger \& Lang, 2008), whose leaders are fair (Lo et al., 2010) and are supportive of their employees. At the same time, a number of scholars (e.g. Bushra, Usman \& Naveed, 2011; Kim \& Brymer, 2011) contended that supervision is one of the significant factors that guide employee commitment to their organization.

\subsection{Influence of Laissez-faire Leadership on Organizational Performance}

Basit et al. (2017) studied the impact of leadership style on employee performance, in a private organization in Malaysia. The results revealed that Laissezfaire leadership had a positive impact on employee performance, which indicated that employee performance would increase when Laissez faire leadership is applied. As compared with other leadership styles, autocratic leadership ( $\mathrm{r}=$ $-.1685, p<.05)$ had a negative correlation with employee performance, Laissez faire leadership $(\mathrm{r}=.241, p<.001)$ had a weak positive correlation with employee performance, while democratic leadership $(\mathrm{r}=.581, p<.001)$ had a strong positive correlation with employee performance. Also, a study by Paisey (2002), on school leadership and its influence on performance showed correlation between the Laissez faire leadership and the school performance in secondary schools in Tanzania established that principals who use the Laissez faire leadership tend to fail to follow up on those they have delegated tasks to and consequently performance declines. Ochieng (2001) established that principals who use the Laissez faire leadership tend to fail to follow up on those they have delegated tasks to and consequently performance declines. They leave everything to the mercy of their staffs, some of whom may lack the necessary skills and competence to execute the work. Others may simply not like to do the work unless they are supervised. This study investigated how Laissez faire leadership influ- 
ences organizational performance of PTTCs in Lake Victoria region of Kenya.

\subsection{Influence of Autocratic Leadership on Organizational Performance}

Nyamboga et al. (2014) studied the impact of principals' leadership style on the performance of students in public secondary schools in Kenya Certificate of Secondary Education in Tana River County. Schools in the county had displayed varied results with varying leadership styles. The county had had a very low mean score between the years 2005-2009. This was in spite of the fact that schools in the region were endowed with appropriate resources (Nyamboga et al., 2014). The findings of the study revealed that there was a significant relationship between head teachers' leadership style and students' performance at KCSE. The principals in Tana River County had an average of autocratic leadership styles which correlated very well with their students' poor performance. Autocratic leadership style was found to have a significant negative effect on the students' performance in national examinations. In another study, Nuhu (2010) studied the effect of leadership on employee performance in Kampaka District Council. The result revealed autocratic leadership had a negative correlation with employee performance $(r=-.422, p<.001)$ which was statistically significant. The finding meant that authoritative leadership affected individual performance in a way that compromised efficiency to work. This study investigated the influence of principals' autocratic leadership style on organizational performance of PTTCs in Lake Victoria Region of Kenya.

\subsection{Influence of Demographic Characteristics on Organizational Performance}

Demographic characteristics are widely acknowledged as having a great influence on staff performance. Fletchl (cited in Thakur, 2015) points out that the demographic characteristics have an influence on whether employees will be committed to their work or not. He observes that how well the employee performs, how many years they are ready to dedicate in service and how well they act in the best interest of the firm's objectives heavily depends on how much the organizations take care of the needs that are related to their demographic characteristics (Thakur, 2015).

\subsection{Influence of Gender on Organizational Performance}

According to Jackson (2003) there are many stereotypes in existence concerning the differences in abilities between men and women in many organizations. Andoh, Biako and Afranie (2011) point out importance of recognizing the fact that there are only a few, gender related differences that will affect the performance of men and women. It is observed that while women are good in obeying rules and following instructions, men on the other hand are more aggressive and aim at seeing the results quickly. The differences are however minor and might not be universally adopted as an explanation as to why men and women attain 
different performance standards (Murray, 2002). Further Murray (2002) added that there are a number of possible explanations to this. Firstly, women are granted a longer maternity leave compared to their male counterparts who just get a few days and sometimes denied depending on the policies of the organizations they are working for. From a cultural context, women are more responsible to immediate family matters such as looking after children more than their male counterparts.

In one study, Thakur (2015) sought to determine the influence of demographic characteristics on performance of academic employees at Kenyatta University in Kenya. Data was collected from the academic staff (Full Professor, Associate Professor, Senior lecturer, lecturer and Tutorial fellows) at Kenyatta University. From the study findings, majority (65\%) of the academic staff were male while $35 \%$ were female. The finding confirmed that gender plays a critical role in employee's performance. From the above results however, this has not yet been fully achieved given the identified gap between the male and female performance.

\subsection{Influence of Age on Employee Performance}

The decline of mental abilities from early adulthood is a universal phenomenon. A large body of evidence supports the notion that cognitive abilities decline from some stage in adulthood (Skirbekk, 2003). Physical abilities, mental abilities, education and job experience form an individual's productivity potential. Combined with organization's characteristics, these factors determine job performance. Productivity reductions at older ages are particularly strong for work tasks where problem solving, learning and speed are needed, while in jobs where experience and verbal abilities are important, older individuals' maintain a relatively high productivity level (Skirbekk, 2003).

A study by Thakur (2015) of the academic staff at Kenyatta University found that most (47\%) of the respondents were aged between 40 - 64 years, $43 \%$ were 39 years and below while 10\% were aged between $65-78$ years, implying that majority of the academic staff at Kenyatta University were aged between 40 - 64 years. The result also established that the age category of 31 to 40 that performs the best also constitutes the highest population per age category among the employees working at Kenyatta University. This indicates that the university is aware of the age factor in as far as productivity is concerned. Although several writers dispute the idea of age as a determinant of productivity, this research proved otherwise. From results above, age is a key determinant of employee performance.

\subsection{Influence of Education Level on Employee Performance}

The current times are seeing education take the central stage in employment. Most employers insist on certain minimum educational qualifications before considering one for a particular job. The recent high rates of unemployment in 
many countries are seeing graduates into accepting jobs that they are either under-qualified or overqualified for (Silva, 2009). According to Easterlin (2007) the skills gained through education are a mark of performance level that an employee can exhibit. However, different fields of specialization are needed in order to meet the labour needs within learning institutions. Griffin \& Moorhead (2011) argued there is a twofold implication to this especially when performance is concerned. Firstly, non-specialized workers might make more errors that can reflect in their work as poor performance standards due to the lack of the basic conceptual background of what they are doing; their productivity level can also be low by virtue of this. Secondly, the level of motivation can be low especially to those who are forced to work in departments that they are less willing to work in but have been forced by circumstances to do so (Griffin \& Moorhead, 2011). This can result in low motivation and poor performance.

Thakur (2015) study which sought to establish the level of education of the respondents, found that majority (58\%) of the respondents had $\mathrm{PhD}$ as their highest level of education while $42 \%$ had Master's degree as their highest level of education. This implied that majority of the academic staff at Kenyatta University had $\mathrm{PhD}$ as their highest level of education. This is expected of the universities because education qualification highly influences their performance at work. The fact that all the academic staff held at least a Master's Degree was indicative of the value that the university attached on education in as far as employee performance is concerned.

\subsection{Influence of Working Experience on Organizational Performance}

Employee's working experience can have a great impact on whether they will perform better or not. Gaining work experiences within an organization means both the employer and employee relationship is sustainable in as far as achieving the goals of the organization is concerned (Yeatts \& Hyten, 1998). A study of San Diego public school teachers between 1997 and 2000 in elementary, middle, and high school found a statistically insignificant relationship between teaching experience and gains in student achievement in math and reading. More specifically, the authors did not find a statistically significant difference between the effectiveness of a fully credentialed elementary teacher with more than 10 years of experience and teachers with fewer years of experience (Kini \& Podolsky, 2016). Unfortunately, the authors did not isolate the returns to experience because they only reported the gains related to the interaction of teachers' credentials (i.e., full, emergency, intern) and their experience. In addition, the authors grouped teachers with 10 or more years of experience together, which limits the inferences that can be drawn about experience past 10 years because the effects of teachers throughout this wide period of time are conflated. The study also found that teachers constantly improved teaching effectiveness until the 21st year. The most effective teachers had $19-24$ years of experience at grade level and were associated, holding all other variables constant, with increased student 
reading achievement (effect size $=.40$ ). These highly experienced teachers were twice as effective as teachers with at least more than five years of experience (effect size $=.20$ ).

\subsection{Influence of Tenure at the Organization on Employee Performance}

The number of years that one has spent within an organization can have an impact on whether they will perform better or not. In addition to gaining work experience, many years of work within an organization indicate that the employer and employee relationship is sustainable in as far as achieving the goals of the organization is concerned (Yeatts \& Hyten, 1998). Over 40 years of teacher productivity research suggests that the simple assumption that "more is better" requires greater nuance; experience effects are complex and depend on a number of factors. Evidence from CALDER studies using rich state datasets provides new insight into the effects of teacher experience (Rice, 2010). Several key findings emerge, some confirming previous understandings and others raising new questions. These findings have important policy implications. Experience matters, but more is not always better. The impact of experience is strongest during the first few years of teaching; after that, marginal returns diminish (Rice, 2010). A number of CALDER studies confirm findings from existing research that, on average, brand new teachers are less effective than those with some experience under their belts (Harris \& Sass, 2007; Ladd, 2008). Early-career experience has a clear payoff in teacher effectiveness, and the impact is stronger than the effect of most other observable teacher-related variables including advanced degrees, teacher licensure tests scores, National Board certification at the elementary level, and class size (Ladd, 2008; Sass, 2007). Teachers show the greatest productivity gains during their first few years on the job, after which their performance tends to level off. A study using New York City data illustrates the diminishing marginal returns to experience (Boyd et al., 2007).

\section{Research Methodology}

This study adopted the survey research design. Survey design provides a quantitative or numeric description of trends, attitudes or opinions of a population by studying a sample of that population. From sample results, the researcher generalizes or makes claims about the population (Creswell, 2003). It entails the collection of data on more than one case and at a single point in time in order to collect a body of quantitative or quantifiable data in connection with two or more variables which are examined to detect patterns of association (Bryman, 2008; Fowler, 2009). This design was found to be appropriate by the researcher because the researcher was studying a sample in order to make generalizations about the population. There was therefore the advantage of identifying the attributes of the population from a small group of individuals. Secondly, the design was found suitable because of enabling the researcher make quantitative 
descriptions of the opinions of the population. The research design enabled the researcher to collect data on the influence of principals' leadership style on organizational performance as moderated by tutors' demographic characteristics. This was a cross sectional study as it involved the collection of data at a single point in time.

\subsection{Target Population}

The target population was all the 254 tutors teaching in the nine selected PTTCs. They comprised 9 principals and 245 other tutors. The respondents held professional certification from universities and other educational institutions recognized by the Kenya government. Tutors in public PTTCs were employed by the Teachers Service Commission (TSC) while those in private contracted locally by the Boards of Management (BoMs) of those PTTCs. The PTTCs are preferred because they have defined administrative structures. Also, they offer the same Primary 1 (P1) course and have legal mandate to operate given by the government of Kenya. Their top leadership structures are almost similar and they are likely to exhibit elaborate relationships between the study variables.

\subsection{Sample Size and Sampling Procedure}

A sample of 234 was obtained from each PTTC. They comprised 9 principals and 225 other members of staff. The formula adopted was the one used by Krejcie \& Morgan (1970) article "Determining Sample Size for Research Activities" (Educational and Psychological Measurement). Its advantage was that PTTCs with a smaller number of tutors were all the tutors were selected, and those PTTCs with a large number of tutors had an appropriate number sampled.

\subsection{Sampling Procedure}

The study employed a multistage sampling procedure. The researcher first used cluster sampling (Creswell, 2003) to get the nine PTTCs from the four counties of Lake Victoria Region. Five public and five private PTTCs were selected for the study. Gender was also considered to ensure both male and female tutors were selected. Purposive non-random sampling, also described as "judgmental" sampling (Mason \& Griffin, 2002) was also employed in which participants were chosen on the basis that they exhibited particular features or experiences that enabled detailed understanding of the central themes and puzzles the researcher wished to study. The logic of using purposive sampling was to select information-rich respondents. In-depth information-rich cases are those from which one can learn a great deal issues of central importance to the purpose of the research, thus the term purposive sampling (Mason \& Griffin, 2002).

\subsection{Instruments for Data Collection}

The study used primary data which was collected using one research instrument, namely, questionnaires. 


\subsection{Validity and Reliability of Research Instruments}

To determine the validity of the items in the research instruments, a pilot study was conducted to the respondents from each category of the subjects. Cronbach's alpha for all the variables were above .7 which is acceptable. The values were interpreted using the following criteria: $\alpha>.9$ excellent, $.9>\alpha>.8$ good, $.8>\alpha>.7$ acceptable, $.7>\alpha>.6$ questionable, and $.6>\alpha>.5$ poor (George \& Mallery, 2010). Results for Laissez faire leadership $(\alpha=.77)$ and autocratic leadership $(\alpha=.70)$ indicated acceptable reliabilities.

\subsection{Data Analysis}

Data collected from the respondents was then checked for completeness. The data obtained from the research questionnaires were analyzed by SPSS version 20. This method of data analysis allowed the researcher to analyze huge amounts of data (Laws et al., 2003). Descriptive analysis was used because the researcher wanted to compare the responses of different groups (Creswell, 2009) and the data were mainly in terms of numbers. Tabulation was a part of the technical procedure wherein the classified data were put in the form of tables (Kothari, 2004). The study presented the means, frequencies, percentages, and standard deviations of participants that belonged to specific categories including gender, age, education level, teaching experience, years of stay in current PTTC, current rank and category of PTTC.

\subsection{Ethical Considerations}

Several moral principles were applied while interacting with respondents including being respectful, fair and promoting healthy relationships. The researcher was cautious and avoided hurting the respondents. The researcher explained and clarified all issues pertaining to the study. There was openness to and honesty with the research participants. The researcher explained to participants the purpose of the study and other information they needed. This step increased their willingness to participate. The researcher maintained confidentiality and also explained the benefits which participants could derive from the research. The researcher obtained "informed consent" letter from the university. Respondents' anonymities were preserved to avoid possible embarrassment for providing certain information (Jonser, 2002).

\section{Research Findings and Discussions}

In Table 1, the findings show that from all tutors who participated in this survey the majority were males tutors $53.9 \%$, females principals $55.6 \%$, tutors age bracket 41 - 50 years $32.6 \%$, principals age bracket $51-60$ years were $77.8 \%$, Tutors educational level $54.4 \%$ bachelor degree, principals $55.6 \%$ bachelor degree, tutors teaching experiences category 18 and above years were $37.3 \%$, principals $77.8 \%$ had teaching experience above 18 year, and lastly years of stay in current PTTC 0 - 5 years were 53.8\%, and for the principals $77.8 \%$ had stayed for 5 years or less. 
Table 1. Demographic characteristics data of respondents.

\begin{tabular}{|c|c|c|c|}
\hline Sample characteristics & Category & Frequency & Percentage \\
\hline \multirow{2}{*}{ 1. Gender } & Male & 104 & 53.9 \\
\hline & Female & 89 & 46.1 \\
\hline \multirow{4}{*}{ 2. Age group } & $21-30$ & 30 & 15.6 \\
\hline & $31-40$ & 45 & 23.3 \\
\hline & $41-50$ & 63 & 32.6 \\
\hline & $51-60$ & 55 & 28.5 \\
\hline \multirow{5}{*}{ 3. Education level } & Doctorate & 1 & .5 \\
\hline & Master & 65 & 33.7 \\
\hline & Bachelor & 105 & 54.4 \\
\hline & Diploma & 17 & 8.8 \\
\hline & Others & 5 & 2.6 \\
\hline \multirow{4}{*}{ 4. Teaching experience } & $0-5$ & 35 & 18.1 \\
\hline & $6-11$ & 38 & 19.7 \\
\hline & $12-17$ & 48 & 24.9 \\
\hline & 18 and above & 73 & 37.3 \\
\hline \multirow{4}{*}{ 5. Tenure in current PTTC } & $0-5$ & 104 & 53.8 \\
\hline & $6-11$ & 58 & 30.0 \\
\hline & $12-17$ & 19 & 10 \\
\hline & $18+$ & 12 & 6.2 \\
\hline
\end{tabular}

Source: Survey data, 2019.

\subsection{Leadership Styles Items}

In Table 2, the results revealed that Laissez faire and autocratic leadership styles were less exhibited by principals of PTTCs in Lake Victoria Region of Kenya. The overall means for the four statements of Laissez faire leadership was 2.16 with a standard deviation of .923 , while the overall mean for the four statements on autocratic leadership was 2.78 with a standard deviation .959 .

\subsection{Finding for Organizational Performance}

In Table 3, the results reveal that organizational performance had a moderate mean of 3.22. The standard deviations of .718 showed acceptable range.

\subsection{Influence of Principals' Leadership Styles on Organizational Performance of PTTCs}

In Table 4, the correlation shows the correlation shows that Laissez faire leadership had a weak negative correlation with organizational performance $(r=$ $-.203 ; p=.005<.05)$. Similarly, autocratic leadership had a weak negative correlation with organizational performance $(\mathrm{r}=-.184 ; p=.011<.05)$. The $p$-values $(p<.005$ and $p<.011)$ show a statistically significant correlation between Laissez faire and autocratic leadership styles and organizational performance. 
Table 2. Summary of leadership styles.

\begin{tabular}{cccc}
\hline Leadership styles & No. of items & Mean & Standard deviation \\
\hline Laissez faire leadership $\left(X_{1}\right)$ & 4 & 2.16 & .923 \\
Autocratic leadership $\left(X_{2}\right)$ & 4 & 2.78 & .959 \\
\hline
\end{tabular}

Source: Survey data (2019).

Table 3. Result for the summary of organizational performance.

\begin{tabular}{ccc}
\hline No. of items & Mean & Standard deviation \\
\hline 6 & 3.22 & .718 \\
\hline
\end{tabular}

Source: Survey data (2019).

Table 4. Correlations result for leadership styles and organizational performance.

\begin{tabular}{|c|c|c|c|c|}
\hline & & 1 & 2 & 3 \\
\hline \multirow{3}{*}{ 1. Organizational Performance } & Pearson Correlation & 1 & & \\
\hline & Sig. (2-tailed) & & & \\
\hline & $\mathrm{N}$ & 193 & & \\
\hline \multirow{3}{*}{ 2. Laissez faire leadership } & Pearson Correlation & $-.203^{\star *}$ & 1 & \\
\hline & Sig. (2-tailed) & .005 & & \\
\hline & $\mathrm{N}$ & 193 & 193 & \\
\hline \multirow{3}{*}{ 3. Autocratic leadership } & Pearson Correlation & $-.184^{\star}$ & $.336^{* *}$ & 1 \\
\hline & Sig. (2-tailed) & .011 & .000 & \\
\hline & $\mathrm{N}$ & 193 & 193 & 193 \\
\hline
\end{tabular}

${ }^{*}$ Correlation is significant at the .01 level (2-tailed). ${ }^{\star}$ Correlation is significant at the .05 level (2-tailed). Source: SPSS output, 2019.

\subsection{Regression Result for Leadership Styles and Organizational Climate}

The regression results of the model are presented in Table $5, \mathrm{R}=.237\left(\mathrm{R}^{2}=.056\right)$ shows that a combination of Laissez faire and autocratic leadership styles account for $5.6 \%$ decrease in organizational performance. Individually, $\mathrm{R}^{2}=.041$ $(\mathrm{R}=.203)$ shows that Laissez faire leadership alone accounts for $4.1 \%$ decrease in organizational performance, while $\mathrm{R}^{2}=.034(\mathrm{R}=.184)$ shows that autocratic leadership alone accounts for $3.4 \%$ decrease in organizational performance. The full model containing all predictors was statistically significant because the $p$-values of .004, .005 and .011 are less than the significant level of .05. Also, according to Field (2013), Durbin-Watson values less than 1 or more than 3 is a cause of concern. Thus, Durbin values 2.200, 2.181 and 2.151 suggest that there is no auto-correlation in our model.

\subsection{ANOVA Results for Leadership Styles and Organizational Performance}

Table 6 presents the analysis of variance (ANOVA) or model fit results. For 
Table 5. Regression result for leadership style and organizational performance.

\begin{tabular}{cccccc}
\hline Model & $\mathrm{R}$ & R Square & Adjusted R Square & $\begin{array}{c}\text { Std. Error of the } \\
\text { Estimate }\end{array}$ & Durbin-Watson \\
\hline 1 & $.237^{\mathrm{a}}$ & .056 & .046 & .70082 & 2.200 \\
2 & $.203^{\mathrm{a}}$ & .041 & .036 & .70453 & 2.181 \\
3 & $.184^{\mathrm{a}}$ & .034 & .029 & .70725 & 2.151 \\
\hline
\end{tabular}

${ }^{\text {al } P r e d i c t o r s: ~(C o n s t a n t), ~ A u t o c r a t i c ~ l e a d e r s h i p, ~ L a i s s e z ~ f a i r e ~ l e a d e r s h i p ; ~}{ }^{2}$ Predictors: (Constant), Laissez faire leadership; ${ }^{a 3}$ Predictors: (Constant), Autocratic leadership; 'Dependent Variable: Organizational Performance. Source: SPSS output, 2019.

Table 6. ANOVA result for leadership styles and organizational performance.

\begin{tabular}{|c|c|c|c|c|c|c|c|}
\hline & & Model & Sum of Squares & Df & Mean Square & $\mathrm{F}$ & Sig. \\
\hline \multirow{3}{*}{ Leadership style } & \multirow{3}{*}{1} & Regression & 5.555 & 2 & 2.777 & 5.655 & $.004^{\mathrm{b}}$ \\
\hline & & Residual & 93.319 & 190 & .491 & & \\
\hline & & Total & 98.873 & 192 & & & \\
\hline \multirow{3}{*}{$\begin{array}{l}\text { Laissez faire } \\
\text { leadership }\end{array}$} & \multirow{3}{*}{2} & Regression & 4.067 & 1 & 4.067 & 8.194 & $.005^{\mathrm{b}}$ \\
\hline & & Residual & 94.806 & 191 & .496 & & \\
\hline & & Total & 98.873 & 192 & & & \\
\hline \multirow{3}{*}{$\begin{array}{l}\text { Autocratic } \\
\text { leadership }\end{array}$} & \multirow{3}{*}{3} & Regression & 3.335 & 1 & 3.335 & 6.668 & $.011^{\mathrm{b}}$ \\
\hline & & Residual & 95.538 & 191 & .500 & & \\
\hline & & Total & 98.873 & 192 & & & \\
\hline
\end{tabular}

a1Predictors: (Constant), Laissez faire leadership, Autocratic leadership; ${ }^{2}$ Predictors: (Constant), Laissez faire leadership; ${ }^{a 3}$ Predictors: (Constant), Autocratic leadership; 'bependent Variable: Organizational performance. Source: SPSS output, 2019.

organizational performance $(\mathrm{F}(2,190)=5.655 ; p=.004<.05)$ meaning the model has power to predict organizational performance significantly from leadership scores. However, the very low regression sum (5.555) as compared the very high residual sum (93.319) indicates that the model does not explain most of the variation in the organizational performance.

For Laissez faire leadership $(\mathrm{F}(1,191)=8.194 ; p=.005<.05)$ meaning the model has power to predict organizational performance significantly from Laissez faire leadership scores. However, the very low regression sum (4.067) as compared the very high residual sum (94.806) indicates that the model does not explain most of the variation in the organizational performance.

For autocratic leadership $(\mathrm{F}(1,191)=6.668 ; p=.011<.05)$ meaning the model has power to predict organizational performance significantly from autocratic leadership scores. However, the very low regression sum (3.335) as compared the very high residual sum (95.538) indicates that the model does not explain most of the variation in the organizational performance.

\subsection{Results for Coefficients for Leadership Styles and Organizational Performance (Table 7)}

The model to be tested was 
Table 7. Results for coefficients for leadership styles and organizational performance.

\begin{tabular}{ccccccc}
\hline \multirow{2}{*}{ Model } & \multicolumn{2}{c}{ Unstandardized Coefficients } & $\begin{array}{c}\text { Standardized } \\
\text { Coefficients }\end{array}$ & \multirow{2}{*}{$\mathrm{T}$} & Sig. \\
\cline { 3 - 5 } & & $\mathrm{B}$ & Std. Error & Beta & & \\
\hline \multirow{2}{*}{1} & (Constant) & 3.762 & .172 & & 21.913 & .000 \\
& Laissez faire & -.124 & .058 & -.159 & -2.126 & .035 \\
& Autocratic & -.097 & .056 & -.130 & -1.740 & .083 \\
\hline
\end{tabular}

a Dependent Variable: Organizational performance. Source: Field data, 2019.

$$
Y=\beta_{0}+\beta_{1} X_{1}+\beta_{2} X_{2}+\beta_{3} X_{3}+\varepsilon
$$

where:

$Y=$ the predicted value for organizational performance

$\mathrm{B}_{0}=$ the $\mathrm{y}$-intercept of regression line (the level of organizational performance in the absence of demographic factors) (3.762)

$\mathrm{B}_{1}=$ the slope of the regression line of Laissez faire leadership (the regression line is decreasing) (-.124)

$B_{2}=$ the slope of the regression line autocratic leadership (the regression line is decreasing) (-.097)

$X_{1}=$ Laisse $z$ faire leadership $(-.157)$

$X_{2}=$ Autocratic leadership $(-.130)$

$\mathrm{E}=$ Error term $(.172+.058+.056=.286)$

$$
Y_{1}=\beta_{0}+\beta_{1} X_{1}+\beta_{2} X_{2}+\varepsilon
$$

Table 8 below shows the performance of the nine colleges in PTE Examinations from 2016 to 219. The performance was examined using a 9-point scale ranging from 1 for best performance and 9 for worst performance. The ranking according to college mean grade is as follows. In first position was COL-01 with a mean grade of 4.98. In second was COL-05 with a mean grade of 5.11, third was COL-09 with a mean grade of 5.28, fourth was COL-04 with a mean grade of 5.37 , fifth was COL-03 with a mean grade of 5.39, sixth was COL-06 with a mean grade of 5.44, seventh was COL-02 with a mean grade of 5.52, eighth was COL07 with a mean grade of 5.54, ninth was COL-08 with a mean grade of 5.65. Despite not having more adequate infrastructural and instructional facilities, public PTTCs still performed better in Primary Teacher Education national examinations with an average mean of 5.27 as compared to private PTTCs with an average mean of 5.65. The finding has supported the position taken by the tutors who took part in the questionnaire survey whose result was a mean score of 3.1 which was an average performance.

Overall, the findings revealed that public PTTCs performed better than private PTTCs in PTE examinations. These results could be attributed to the fact that public PTTCs had better learning facilities and more established staffs. However, the findings were not in agreement with the tutors' responses in the questionnaire that PTTCs in Lake Victoria Region of Kenya perform above average (3.61) in co-curricular activities. 
Table 8. Performance of colleges in PTE examination between 2016-2019.

\begin{tabular}{cccccccccc}
\hline PTTC & \multicolumn{1}{c}{ COL 01 } & COL 05 COL 04 COL 03 & COL 02 & COL 09 & COL 06 & COL 07 & COL 08 \\
\hline 2016 & 4.64 & 5.23 & 5.07 & --- & 5.47 & $\ldots$. & 5.36 & 5.19 & 5.39 \\
2017 & 5.18 & 5.82 & 5.84 & $\ldots \ldots$ & 5.71 & $\ldots$. & 5.74 & 5.88 & 5.50 \\
2018 & 4.94 & 4.47 & 5.55 & 5.48 & 5.46 & 5.87 & 5.63 & 5.58 & 5.47 \\
2019 & 5.16 & 4.92 & 4.99 & 5.31 & 5.47 & 4.69 & 5.44 & 5.49 & 5.43 \\
AVERAGE & $\mathbf{4 . 9 8}$ & 5.11 & $\mathbf{5 . 3 7}$ & $\mathbf{5 . 3 9}$ & $\mathbf{5 . 5 2}$ & $\mathbf{5 . 2 8}$ & $\mathbf{5 . 4 4}$ & $\mathbf{5 . 5 4}$ & $\mathbf{5 . 6 5}$ \\
RANK & $\mathbf{1}$ & $\mathbf{2}$ & $\mathbf{4}$ & $\mathbf{5}$ & $\mathbf{7}$ & $\mathbf{3}$ & $\mathbf{6}$ & $\mathbf{8}$ & $\mathbf{9}$ \\
\hline
\end{tabular}

Source: Field data (2019).

\subsection{Influence of Demographic Factors on Organizational Performance}

In Table 9, the correlation shows that demographic factors had negligible correlation with organizational performance. Gender $(\mathrm{r}=-.042, p=.560>.05)$; age $(\mathrm{r}=-.038, p=.600>.05)$; education level $(\mathrm{r}=.062, p=.390>.05)$; teaching experience $(\mathrm{r}=-.045, p=.537>.05)$; and lastly years of stay in current PTTC ( $\mathrm{r}$ $=.062, p=.391>.05)$. None of the demographic factors was statistically significant at $5 \%$ because the $p$-values of $.560, .600, .390, .537$ and .391 are more than the significant level of 05 .

\subsection{Regression Result for Demographic Factors on Job Satisfaction of Tutors in PTTCs}

In Table 10, a summary of multiple linear regression results of the model for the demographic factors are presented. The $\mathrm{R}^{2}=.009$ shows that demographic factors account for only . $9 \%$ variation in organizational performance. Also, Durbin value of 2.073 suggests that there is no auto-correlation in our model.

\subsection{ANOVA Results for Demographic Factors on Staff Organizational Performance}

Table 11 presents the analysis of variance (ANOVA) or model fit results. For demographic factors $(\mathrm{F}(5,187)=.343 ; p=.886>.05)$ meaning the model does not have power to predict organizational performance significantly from demographic scores. Also, the very low regression sum (.899) as compared the very high residual sum (97.974) indicates that the model does not explain the variation in the organizational performance.

\subsection{Coefficients Results for Demographic Factors on Organizational Performance (Table 12)}

The model to be tested was

$$
Y_{2}=\beta_{0}+\beta_{1} X_{1}+\beta_{2} X_{2}+\beta_{3} X_{3}+\beta_{4} X_{4}+\beta_{5} X_{5}+\varepsilon
$$

where:

$$
Y_{2}=\text { the predicted value for organizational performance }
$$


Table 9. Correlations results for demographic factors and staff organizational performance.

\begin{tabular}{|c|c|c|c|c|c|c|c|}
\hline & & 1 & 2 & 3 & 4 & 5 & 6 \\
\hline \multirow{3}{*}{$\begin{array}{l}\text { 1. Organizational } \\
\text { performance }\end{array}$} & Pearson Correlation & 1 & & & & & \\
\hline & Sig. (2-tailed) & & & & & & \\
\hline & $\mathrm{N}$ & 193 & & & & & \\
\hline \multirow{3}{*}{ 2. Gender } & Pearson Correlation & -.042 & 1 & & & & \\
\hline & Sig. (2-tailed) & .560 & & & & & \\
\hline & $\mathrm{N}$ & 193 & 193 & & & & \\
\hline \multirow{3}{*}{ 3. Age } & Pearson Correlation & -.038 & -.035 & 1 & & & \\
\hline & Sig. (2-tailed) & .600 & .628 & & & & \\
\hline & $\mathrm{N}$ & 193 & 193 & 193 & & & \\
\hline \multirow{3}{*}{$\begin{array}{l}\text { 4. Educational } \\
\text { level }\end{array}$} & Pearson Correlation & .062 & -.096 & -.139 & 1 & & \\
\hline & Sig. (2-tailed) & .390 & .185 & .053 & & & \\
\hline & $\mathrm{N}$ & 193 & 193 & 193 & 193 & & \\
\hline \multirow{3}{*}{$\begin{array}{l}\text { 5. Teaching } \\
\text { experience }\end{array}$} & Pearson Correlation & -.045 & -.051 & $.736^{\star *}$ & $-.256^{* *}$ & 1 & \\
\hline & Sig. (2-tailed) & .537 & .483 & .000 & .000 & & \\
\hline & $\mathrm{N}$ & 193 & 193 & 193 & 193 & 193 & \\
\hline \multirow{3}{*}{$\begin{array}{l}\text { 6. Years of stay in } \\
\text { current TTC }\end{array}$} & Pearson Correlation & -.062 & -.064 & $.302^{\star *}$ & -.067 & $.388^{\star *}$ & 1 \\
\hline & Sig. (2-tailed) & .391 & .373 & .000 & .356 & .000 & \\
\hline & $\mathrm{N}$ & 193 & 193 & 193 & 193 & 193 & 193 \\
\hline
\end{tabular}

${ }^{* *}$ Correlation is significant at the .01 level (2-tailed).

Table 10. Model summary for demographic factors on organizational performance.

\begin{tabular}{cccccc}
\hline Model & $\mathrm{R}$ & R Square & Adjusted R Square & $\begin{array}{c}\text { Std. Error of the } \\
\text { Estimate }\end{array}$ & Durbin-Watson \\
\hline 1 & $.095^{\mathrm{a}}$ & .009 & -.017 & .72383 & 2.073 \\
\hline
\end{tabular}

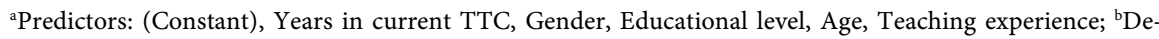
pendent Variable: Organizational performance. Source: Field data, 2020.

Table 11. ANOVA for demographic factors on organizational performance.

\begin{tabular}{ccccccc}
\hline \multicolumn{2}{c}{ Model } & Sum of Squares & df & Mean Square & F & Sig. \\
\hline & Regression & .899 & 5 & .180 & .343 & $.886^{\text {b }}$ \\
1 & Residual & 97.974 & 187 & .524 & \\
& Total & 98.873 & 192 & & \\
\hline
\end{tabular}

a Dependent Variable: Organizational performance; 'Predictors: (Constant), Years in current TTC, Gender, Educational level, Age, Teaching experience.

$\mathrm{B}_{0}=$ the $\mathrm{y}$-intercept of regression line (the level of organizational performance in the absence of demographic factors) (3.252)

$\mathrm{B}_{1}=$ the slope of the regression line of gender (the regression line is decreasing) (-.057) 
Table 12. Coefficients for intervening variables and organizational performance.

\begin{tabular}{|c|c|c|c|c|c|c|}
\hline & \multirow{2}{*}{ Model } & \multicolumn{2}{|c|}{ Unstandardized Coefficients } & \multirow{2}{*}{$\begin{array}{c}\text { Standardized } \\
\text { Coefficients } \\
\text { Beta }\end{array}$} & \multirow[t]{2}{*}{$\mathrm{t}$} & \multirow{2}{*}{ Sig. } \\
\hline & & B & Std. Error & & & \\
\hline \multirow{6}{*}{1} & (Constant) & 3.252 & .338 & & 9.632 & .000 \\
\hline & Gender & -.059 & .105 & -.041 & -.564 & .574 \\
\hline & Age in years & -.005 & .038 & -.015 & -.135 & .893 \\
\hline & Educational level & .053 & .076 & .052 & .687 & .493 \\
\hline & Teaching experience & .000 & .036 & -.001 & -.007 & .995 \\
\hline & Years in current TTC & -.022 & .031 & -.057 & -.715 & .476 \\
\hline
\end{tabular}

Dependent Variable: Organizational performance. Source: Fiend data, 2019.

$\mathrm{B}_{2}=$ the slope of the regression line age (the regression line is decreasing) $(-.005)$

$\mathrm{B}_{3}=$ the slope of the regression line of educational level (the regression line is increasing) (.053)

$\mathrm{B}_{4}=$ the slope of the regression line of teaching experience (the regression line is constant) (.000)

$\mathrm{B}_{5}=$ the slope of the regression line of stay in current PTTC (the regression line is decreasing) (.022)

$$
\begin{aligned}
& X_{1}=\text { Gender }(-.041) \\
& X_{2}=\text { Age }(-.015) \\
& X_{3}=\text { Educational level }(.052) \\
& X_{4}=\text { Teaching experience }(.001) \\
& X_{5}=\text { Years of stay in current PTTC }(-.057) \\
& \varepsilon=\text { Error term } \\
& \qquad Y_{2}=\beta_{0}+\beta_{1} X_{1}+\beta_{2} X_{2}+\beta_{3} X_{3}+\beta_{4} X_{4}+\beta_{5} X_{5}+\varepsilon
\end{aligned}
$$

\section{Summary of the Findings}

Laissez-faire leadership had a mean of 2.16 and autocratic leadership a mean of 2.78 meaning they were less exhibited by principals of PTTCs in Lake Victoria Region of Kenya (Table 2). The results show that one unit increase in Laissez faire and autocratic leadership styles combined had a correlation of $\mathrm{r}=-.237\left(\mathrm{R}^{2}\right.$ $=.056$ ) meaning $5.6 \%$ decrease in organizational performance (Table 7). Individually, Laissez faire leadership showed varying results with organizational performance. Laissez faire leadership showed a weak negative correlation $\mathrm{R}=.203$ $\left(\mathrm{R}^{2}=.041\right)$ with organizational performance implying $4.1 \%$ decrease in organizational performance, lastly autocratic leadership showed a weak negative correlation $\mathrm{R}=.184\left(\mathrm{r}^{2}=.034\right)$ with organizational performance implying $3.4 \%$ decrease in organizational performance.

The $p$-values $(p=.004)$ for Laissez faire and automatic leadership styles combined, and organizational performance, $(p=.005)$ for Laissez faire and organiza- 
tional performance, and lastly, $(p=.011)$ for automatic leadership and organizational performance (Table 5 ) at .05 significance level indicate a statistically significance correlation between principals' leadership styles and the organization performance.

Also, the five demographic characteristics (gender, age, education level, teaching experience, and tenure) that were studied, explained only $.9 \%$ of organizational performance of PTTCs in Lake Victoria Region of Kenya (Table 10). This was negligible; other factors not studied in this research explained $99.1 \%$. Also the model was found to be statistically insignificant $(p=.886>.05)$. Therefore, the results of the demographics: gender, age, educational level, teaching experience, and tenure in current PTTCs cannot be generalized to be a true reflection at the national level. In summary, increase in Laissez faire and autocratic leadership styles are detrimental to the organizational performance of the PTTCs in Lake Victoria Region of Kenya.

\section{Recommendations}

This study recommends that principals of PTTCs should use less of Laissez faire and autocratic leadership styles since they have negative influence on the organizational performance of PTTCs. Embracing Laissez faire and autocratic leadership styles would decrease organizational performances of PTTCs in both academic and co-curricular activities. Demographic characteristics do not play a critical role in tutors' performances and therefore should not be over-emphasized when appointing tutors to be principals of PTTCs.

\section{Conflicts of Interest}

The authors declare no conflicts of interest regarding the publication of this paper.

\section{References}

Andoh, Biako and Afranie (2011). The Importance of Demographic Characteristics on Employees' Performance Dimensions.

Armstrong, M. (2012). Armstrong's Handbook of Management and Leadership: Developing Effective People Skills for Better Leadership and Management (3rd ed.). Kogan Page.

Basit, A., Sebastian, V., \& Hasan, Z. (2017). Impact of Leadership Style on Employees Performance. A Case Study on a Private Organization in Malaysia. International Journal of Accounting and Business Management, 5, 112-130.

Bass, B. M. (1985). Leadership and Performance beyond Expectations. Free Press.

Bass, B. M. (1999). Two Decades of Research and Development in Transformational Leadership. European Journal of Work and Organizational Psychology, 8, 9-32. https://doi.org/10.1080/135943299398410

Boyatzis, R. E., Golema Irann, D., \& Mckee, A. (2002). Primal Leadership: Realizing the Power of Emotional Intelligence. Harvard Business Press.

Boyd, D. J., Lankford, H., Loeb, S., Rockoff, J. E., \& Wyckoff, J. H. (2007). The Narrowing 
Gap in New York City Teacher Qualifications and Its Implications for Student Achievement in High-Poverty Schools. CALDER Working Paper 10, The Urban Institute. https://doi.org/10.3386/w14021

Bryman, A. (2008). Social Research Methods. O.U.P.

Bushra, F., Usman, A., \& Naveed, A. (2011). Effect of Transformational Leadership on Employees' Job Satisfaction and Organizational Commitment in Banking Sector of Lohre. Islamic University.

Cangemi, J. P. (2008). Leadership Behavior and Organizational Climate. https://www.regent.edu

Chung, K. S., \& Lo, A. (2007). Foundations of Dominant Strategy Mechanisms. Review of Economic Studies, 74, 447-476. https://doi.org/10.1111/j.1467-937X.2007.00427.x

Cloete, M. (2011). The Relationship between Leadership Styles and Organizational Climate. Master's Dissertation, University of South Africa.

Creswell, J. (2003). Research Design-Qualitative, Quantitative and Mixed Methods Approaches (2nd ed.). SAGE Publications.

Creswell, J. W. (2009). Research Design: Qualitative, Quantitative, and Mixed Methods Approaches (3rd ed.). Sage Publications, Inc.

Easterlin, R. A. (2007). Relative Income, Happiness and Utility: An Explanation for the Easterlin Paradox and Other Puzzles. Discussion Paper No. 2840, IZAM.

Farlex (2012). The Dictionary. https://encyclopedia.thefreedictionary.com/

Farrell, N. (2009). What's Your Leadership Style? Woman Advocate, 14, 7-15.

Fernández, E. (2003). Organizational Culture and Human Resource in the Environmental Issue: A Review of the Literature. The International Journal of Human Resource Management, 14, 634-656. https://doi.org/10.1080/0958519032000057628

Field, A. (2013). Discovering Statistics Using IBM SPSS Statistics: And Sex and Drugs and Rock "N" Roll. 4th Edition, Sage, Los Angeles, London, New Delhi.

Fletchl, V. (2010). Work Life Balance-A Comparative Study of Women in Senior Management Positions in Austria, Denmark and Great Britain. GRIN Verlag.

Fowler, F. J. (2009). Survey Research Methods (4th ed.). Sage Publishers. https://doi.org/10.4135/9781452230184

George, D., \& Mallery, P. (2010). SPSS for Windows Step by Step: A Simple Guide and Reference, 18.0 Update (11th ed.). Allyn and Bacon.

Gill, E. (2014). What Is Laissez-Faire Leadership? How Autonomy Can Drive Success. http://online.stu.edu/laissez-faire-leadership

Greenberg, J. (2004). Stress Fairness to Fare No Stress: Managing Workplace Stress by Promoting Organizational Justice. Organizational Dynamics, 33, 352-365. https://doi.org/10.1016/j.orgdyn.2004.09.003

Griffin, R. W., \& Moorhead, G. (2011). Organizational Behavior (10th ed.) Cengage Learning.

Harper, S. (2012). The Leader Coach: A Model of Multi-Style Leadership. Journal of Practical Consulting, 4, 22-31.

http://www.regent.edu/acad/global/publications/jpc/vol4iss1/JPC Vol4Iss1_Harper.pdf

Harris, D. N., \& Sass, T. R. (2007). Teacher Training, Teacher Quality, and Student Achievement. CALDER Working Paper 3, The Urban Institute.

https://doi.org/10.1037/e722772011-001

Hayles and Mendez (1997). Effective Diversity Management of Expecting and New Parents. https://core.ac.uk 
Jackson, D. L. (2003). Revisiting Sample Size and Number of Parameter Estimates: Some Support for the N:q Hypothesis. Structural Equation Modeling, 10, 128-141. https://doi.org/10.1207/S15328007SEM1001 6

Jeremy, M., Melinde, C., \& Ciller, V. (2012). Perceived Leadership Style and Employee Participation in a Manufacturing Company in the Democratic Republic of Congo. African Journal of Business Management, 6, 5389-5398. https://doi.org/10.5897/AJBM11.2443

Jonser, E. (2002). Impact of Leadership Styles on Organizational Performance. Journal of Human Resources Management Research, 2018, Article ID: 687849.

Kerego, K., \& Mthupha, D. M. (1997). Job Satisfaction as Perceived by Agricultural Extension Workers in Swaziland. South African Journal of Agricultural Extension, 23, 19-24.

Khumalo, L. (2015). The Impact of Leadership Styles on Organizational Commitment. Master's Thesis, University of South Africa.

Kim, W. G., \& Brymer, R. A. (2011). The Effects of Ethical Leadership on Manager Job Satisfaction, Commitment, Behavioral Outcomes, and Firm Performance. International Journal of Hospitality Mangement, 30, 1020-1026.

Kini, T., \& Podolsky, A. (2016). Does Teaching Experience Increase Teacher Effectiveness? A Review of the Research. Learning Policy Institute.

Kothari, C. R. (2004). Research Methods: Methods and Techniques (2nd revised ed.).

Krejcie, R. V., \& Morgan, D. W. (1970). Determining Sample Size for Research Activities. Educational and Psychological Measurement, 30, 607-610. https://doi.org/10.1177/001316447003000308

Ladd, H. F. (2008). Teacher Effects: What Do We Know? Teacher Quality Conference at Northwestern University, Duke Durham.

Laws, S., Harper, C., \& Marcus, R. (2003). Research for Development. A Practical Guide. SAGE Publications. https://doi.org/10.4135/9781849209786

Lo, M. C., Rimayah, T., Min. H. W., \& Sonan, P. (2010). The Relationship between Leadership Styles and Organizational Commitment in Malaysia: Role of Leader-Member Exchange. Asia Pacific Business Review, 16, 79-103.

Mason, C., \& Griffin, M. (2002). Group Absenteeism and Positive Affective Tone: A Longitudinal Study. Journal of Organizational Behavior, 24, 667-684. https://doi.org/10.1002/job.210

Mat, J. (2008). The Influence of Leadership Style on Internal Marketing in Retailing. PhD Thesis, University of Stirling.

McGregor, D. M. (1966). The Human Side of Enterprise. McGraw-Hill.

McNamara, M., Bohle, P., \& Quinlan, M. (2011). Precarious Employment, Working Hours, Work-Life Conflict, and Health in Hotel Work. Applied Ergonomics, 42, 225-232. https://doi.org/10.1016/j.apergo.2010.06.013

Murray, C. (2002, May). IQ and Income Inequalities in a Sample of Sibling Pairs from Advantaged Family Backgrounds. The American Economic Review, 92, 339-363. http://www.jstor.org/stable/3083428 https://doi.org/10.1257/000282802320191570

Ng'ethe, J. M., Namusonge, G. S., \& Iravo, M. A. (2012). Influence of Leadership Style on Academic Staff Retention in Public Universities. International Journal of Business and Social Science, 3, 297-302. http://ijbssnet.com/journals/Vol 3 No 21_November_2012/31.pdf

Northouse, P. G. (2007). Leadership: Theory and Practice (4th ed.). Sage Publications. 
Nuhu, K. (2010). Effects of Leadership Style on Employee Performance in Kampala District Council. Master's Thesis, Makerere University.

Nwokocha, I., \& Iheriohanma, E. B. J. (2015). Nexus between Leadership Styles, Employee Retention and Performance in Organizations. European Scientific Journal, 11, 186-209.

Nyamboga, T. O., Gwiyo, J. S., Njuguna, F. W., Waweru, S. N., Nyamweya, B. O., \& Gongera, G. (2014). A Critical Review of the Leadership Styles on the Performance of Public Secondary Schools in National Examinations in Tana River County, Kenya. Journal of Education and Practice, 5, 197-220. https://www.iiste.org

Ochieng, A. H. (2001). Students Academic Performance in K.C.S.E and Leadership Style of Head Teachers Mombasa. Unpublished Master's Thesis, Kenyatta University.

Paisey, A. (2002). Organization and Management in Schools (2nd ed.). Longman Publishing.

Puni, A., Ofei, S. B., \& Okoe, A. (2014). The Effect of Leadership Styles on Firm Performance in Ghana. International Journal of Marketing Studies, 6, 177-185. https://doi.org/10.5539/ijms.v6n1p177

Rice, J. K. (2010). The Impact of Teacher Experience Examining the Evidence and Policy Implications. National Centre for Analysis of Longitudinal Data in Educational Research, Urban Institute.

Rowe, K. J., Stephanou, A., \& Hoad, K-A. (2007). A Project to Investigate Effective "Third Wave" Intervention Strategies for Students with Learning Difficulties Who Are in Mainstream Schools in Years 4, 5 and 6. Final Report to the Australian Government Department of Education, Science and Training. Camberwell, VIC: Australian Council for Educational Research.

Rowold, J. (2011). Relationship between Leadership Behaviors and Performance: The Moderating Role of a Work Team's Level of Age, Gender, and Cultural Heterogeneity. Leadership and Organization Development Journal, 32, 625-647.

https://doi.org/10.1108/01437731111161094

Silva, E. (2009). Measuring Skills for 21st Century Learning. The Phi Delta Kappan, 90, 630-634. https://doi.org/10.1177/003172170909000905

Skirbekk, V. (2003). Age and Individual Productivity: A Literature Survey. Vienna Yearbook of Population Research, 2, 133-153.

Steyrer, J., Schiffinger, M., \& Lang, R. (2008). Organizational Commitment-A Missing Link between Performance Leadership and Organizational Performance. Scandinavian Journal of Management, 24, 364-374.

Thakur, G. (2015). The Influence of Demographic Characteristics on Performance of Academic Employees in Kenyatta University. Master's Thesis, University of Nairobi.

Wu, F. Y., \& Shiu, C. (2009). The Relationship between Leadership Styles and Foreign English Teachers Job Satisfaction in Adult English Cram Schools: Evidences in Taiwan. The Journal of American Academy Business, Cambridge, 14.

$\mathrm{Xu}, \&$ Cooper, T. (2011). How Can Leaders Achieve High Employee Engagement? Leadership and Organizational Development Journal, 32, 399-416. https://doi.org/10.1108/01437731111134661

Yeatts, D. E., \& Hyten, C. (1998). High-Performing Self-Managed Work Teams: A Comparison of Theory and Practice. Sage Publications. https://doi.org/10.4135/9781483328218

Yukl, G. (2013). Leadership in Organizations (8th (Global) ed.). Pearson Education. 